\title{
JURNALELE BLOCURILOR \\ Un exemplu de cercetare interdisciplinară realizată în comunitățile dezvoltate în locuințele colective socialiste din București/
}

\section{TYPE-APARTMENT BUILDING BLOCKS' DIARIES}

\section{An Example of Interdisciplinary Reasearch Developed in Communities of the Type Apartment Socialist Building Blocks in Bucharest}

\author{
Cristina-Gențiana DUMITRAȘCU, asist. dr. arh./ assist. PhD. arch. \\ Universitatea de Arhitectură şi Urbanism „Ion Mincu”, Bucureşti, RO/ \\ „Ion Mincu” University of Architecture and Urbanism, Bucharest, RO
}

gentianacristinaiacob@yahoo.ro

\begin{abstract}
Rezumat
Jurnalele Blocurilor este o platformă care încurajează dezvoltarea de metode alternative de a investiga, analiza și proiecta arhitectura. Proiectul își propune să reconsidere relația ierarhică dintre arhitect și utilizatorul spațiului, aducând la un loc, profesioniști, arhitecți, studenți de la facultățile de arhitectură și design și locuitori ai locuințelor colective tipizate socialiste, într-un proces etapizat, pentru a asigura transmiterea reciprocă de informație. Acest proces include documentare teoretică, analiză, interviuri, ateliere de desen și machetare, mici evenimente expoziționale, care se vor desfășura tot în cartier, ateliere de co-design, o
\end{abstract}

\begin{abstract}
Type-apartment building blocks' Diaries (Jurnalele Blocurilor) is a platform which encourages the development of alternative ways of investigating, analysing and building architecture. This project aims to reconsider the hierarchical relationship between the architect and the user of the space, connecting, in the same time professionals, architects, architectural and design students and inhabitants of the socialist type-apartment building blocks, in a staged process, to ensure the mutual transmission of information. This process will include theoretical documentation, analysis, interviews, drawing and modelling workshops, small
\end{abstract}


platformă online de documentare și o publicație cu rezultatele întregului proces.

Acest articol va aduce în discuție rezultatele celor două prime evenimente, Vernisaj de Cartier și Ceai in Cartier/ Ce ai în Cartier?, care aparțin primului an de cercetare din cadrul proiectului Jurnalele Blocurilor, o cercetare multidisciplinară a trei comunități formate din locuințe colective socialiste tipizate.

\section{Cuvinte cheie/ Keywords}

cercetare interdisciplinară, benzi desenate arhitecturale, secvență, locuințe colective tipizate socialiste/ interdisciplinary research, architectural comics, sequence, socialist type-apartment building block

\section{Introducere}

Clădirile nu rămân niciodată așa cum le-a proiectat arhitectul. Când arhitectul proiectează o clădire, acesta modelează și viața viitorului utilizator al spațiului, iar atunci când cel care ocupă clădirea începe să locuiască spațiul construit, modelează, la rândul său, arhitectura. Putem, întotdeauna, să găsim dovezi arhitecturale ale faptului că întreaga construcție începe să se schimbe, să trăiască și să crească alături de cel care o locuiește, câștigând, în mod constant, noi înțelesuri, odată cu fiecare transformare prin care trece, de-a lungul anilor. În final, spațiul rezultat va fi o imensă arhivă care va fi capabilă să explice, în detaliu, felul în care a trăit cel care l-a locuit (Biciușcă 2005). De altfel, spațiul pe care fiecare dintre noi îl utilizăm zi de zi, câștigă, dea lungul anilor, numeroase suprapuneri de amintiri neighbourhood-friendly exhibitions, co-design workshops, co-design workshops, an online documentation platforms and a short publication with the results of the entire process.

This article will discuss the results of the first two events, Neighbourhood's Opening (Vernisaj de Cartier) and Tea in the Neighbourhood (Ceai în Cartier/ Ce ai în Cartier?) belonging to the first year of research within Type-apartment building blocks' Diaries project, a multidisciplinary investigation of three communities living in socialist type-apartment buildings. 
în fiecare colţ al compoziției sale. O arhivă stratificată și vie este conținută atât în locuitorul spațiului, cât și în pereții clădirii, iar locuitorii pot, oricând, să-i acceseze dosarele. Astfel, întreaga clădirea adună, sub acoperișul ei, o selecție de arhive, închise în locuitorii ei și în spațiile care adăpostesc amintirile acestora.

Conducătorii regimurilor totalitare au considerat, fiecare la rândul său, că reprezentau un simbol al celei mai înalte forme de evoluție tehnologică și arhitecturală, astfel, au propus, de fiecare dată, o arhitectură categorică, definită de construcții de mari dimensiuni, uniforme, promovând o renunțare la cercetări legate de stil, confort sau studii sociale. În contextul realismului socialist, arhitectura devine, la fel ca celelalte arte, un alt instrument de propagandă a partidului comunist, definită de o continuă amăgire a utilizatorului spațiului. Dezvoltarea locuințelor este una dintre prioritățile partidului, pentru a menține, așa cum menționează tema programului, " continua înflorire materială și spirituală a poporului român și ridicarea gradului de civilizație a întregii societăți” (Zahariade 2011, 44).

Între anii 1950-1989, clădirile de locuințe trebuiau proiectate luând în calcul, în primul rând, eficiența economică, devenind, astfel, centrul proiectării tipizate. Locuința colectivă tipizată este consecventă $\mathrm{cu}$ retorica Partidului Comunist, care sublinia necesitatea egalității între oameni, conducătorii refuzând să ia în calcul orice dorință, aspirație sau diferență care putea exista în cei care urmau să locuiască în aceste spații, deoarece toate problemele locuitorului erau considerate rezolvate, pe deplin, de felul în care noua societate se construia (loan 1999). archive is now enclosed in the user of the space and in the composition of the building and the inhabitants can always access its files. The entire building is, in fact, a selection of archives, enclosed in the inhabitants and in the spaces that host their memories.

The leaders of the totalitarian regimes considered, one at a time, that they were a symbol of the last stage of human, technological and architectural evolution, so, each time, they have proposed a categorical architecture, defined by large, uniform constructions, promoting a renouncement of stylistic searches, comfort or social studies. In the context of socialist realism, architecture becomes, like other arts, another communist party propaganda tool, defined by a continuous deception of the user of the space. Housing development was one of the priorities of the Communist Party's agenda, in order to maintain, as the theme-program mentions, „a persisting blooming, both material and spiritual, of the Romanian people" (Zahariade 2011, 44).

Throughout the years 1950-1989, the dwellings had to be designed taking into account, first of all, the best possible economic efficiency, thus, becoming the centre of the typified design. The type apartment-building is definitely consistent with the Party's entire rhetoric, which underlined the necessity of the equality of people, the rulers refusing to consider any desire, aspiration or difference which could exist between the future inhabitants of the space, because all the users' problems were considered completely fully solved by the way the new society was built (Ioan, 1999). 


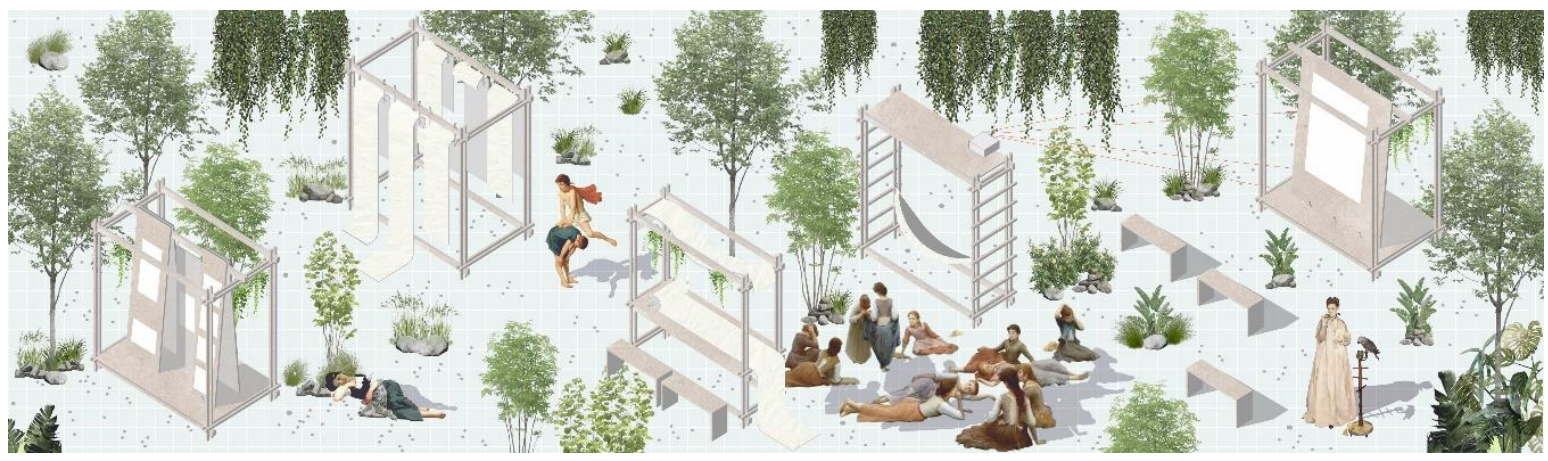

Fig. 1. Imagine cu modulele folosite în timpul evenimentelor Vernisaj de Cartier și Ceai în Cartier/ Ce ai în Cartier? Imagine realizată de Gențiana Dumitrașcu și Andrei Dumitrașcu/

Illustration with the modules used in Neighbourhood's Opening and Tea in the Neighbourhood events.

Image by Gențiana Dumitrașcu and Andrei Dumitrașcu.

\section{Obiective}

Scopul proiectului Jurnalele Blocurilor este să creeze, pentru profesioniști, un alt fel de arhivă detaliată, ce va conține informații complexe care vor fi furnizate, într-un mediu controlat, direct de la locuitorii spațiului pe care îl vom investiga și analiza, gata să fie accesată în momentele în care vor proiecta contribuțiile lor asupra locuințelor colective socialiste tipizate. De asemenea, este o oportunitate de a aminti profesioniștilor potențialul elementului narativ al arhitecturii și de faptul că locuitorii acestor locuințe colective nu reprezintă un singur client universal, ci sunt o multitudine de indivizi care dețin povești puternice și au adunat amintiri valoroase în spațiile pe care le-au ocupat. Rezidenții locuințelor colective vor fi încurajați să contribuie, într-o serie de evenimente participatorii, oferindu-le ocazia de a consolida comunitatea din care fac parte, care, în multe cazuri, este slab conturată, în timp ce vor fi

\section{Objectives}

The aim of the project Type-apartment building blocks' Diaries is to create, for professionals, a different kind of detailed archive, with complex information, which will come, in a guided manner, directly from the users of the spaces, which we will investigate and analyse, ready to be accessed when they will design their contributions for the socialist type-apartment building blocks. Also, it is an opportunity to remind professionals, the power of the narrative aspect of architecture and the fact that the dwellers are not one universal individual client, but a multitude of specific individuals, who have powerful stories and have gathered valuable memories in the spaces they have occupied. The inhabitants of the building blocks will be encouraged to take part in a series of participatory events, strengthening the community which they belong to, that in many cases, is poorly outlined, while also, 
puși în legătură cu o gamă variată de actori civici. Prin asumarea rolului de detectiv al spațiului vor avea șansa de a prelucra rezultatele investigației lor, analizând experiența de a trăi într-una dintre cele mai comune dar și controversate construcții ale arhitecturii românești, produsă de regimul totalitar. Locuitorii vor avea, de asemenea, șansa de a contribui, alături de specialiști, la remedierea unor situații problematice, care au apărut în timpul procesului de locuire. giving them a chance to connect with a different variety of civic actors. By assuming the role of the detective of the space they will have the chance to process the results of their investigation, analysing the experience of living in one of the most common, but controversial construction of Romanian architecture, produced by the totalitarian regime. The residents will also have the chance to contribute, along specialists, to the remediation of some of the challenging issues which appear during the housing process.

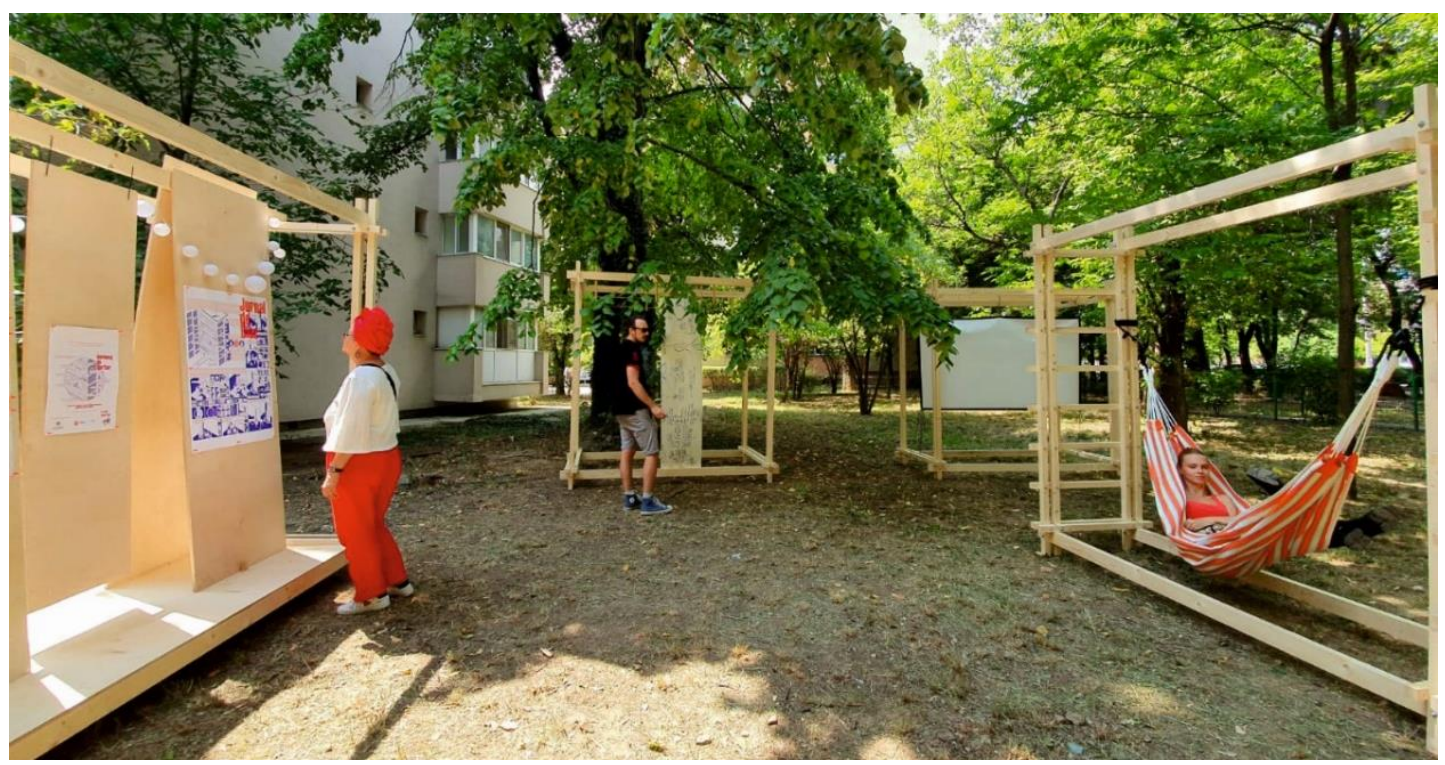

Fig. 2. Vernisaj de Cartier. Imagine de Gențiana Dumitrașcu/ Neighbourhood's Opening. Image by Gențiana Dumitrașcu.

Obiectivul celor două evenimente prezentate în acest articol, care fac parte din prima fază de cercetare a proiectului Jurnalele Blocurilor, Vernisaj de Cartier și Ceai în Cartier/ Ce ai în Cartier?, a fost
The objective for the two events detailed in this article, belonging to the first research phase of the Type-apartment building blocks' Diaries project, Neighbourhood's Opening (Vernisaj de Cartier) and 
să folosim o abordare interdisciplinară pentru a începe un alt tip de analiză arhitecturală, prin discuții, sondaje, interviuri, un jurnal colectiv scris și desenat, care va începe să exploreze straturile suprapuse de semnificații din arhitectura clădirilor de locuinte colective, pe care noi am început deja să le studiem folosind intersecțiile dintre banda desenată și arhitectură.

\section{Materiale și Metode}

Proiectul Jurnalele Blocurilor poate servi drept centru social și spațiu informal de învățare pentru toate părțile implicate, negociind ierarhii, deschizând dialoguri și subliniind faptul că arhitectura este un proces, atunci când este proiectată, dar și atunci când este utilizată. Acest program va funcționa ca un teren de testare pentru noi metode de învățare, abordând, în altă manieră, experiența de documentare și de cercetare, valorificând totodată cunoștințele dobândite în viața cotidiană, alături de locuitorii spațiului.

Programul proiectului reunește oameni din medii diferite și permite schimburi informale de cunoștințe, iar majoritatea etapelor proiectului se vor desfășura în colaborare cu locuitorii. Această abordare crește gradul de conștientizare și vizibilitate al acestei platforme de cercetare și învățare, creând, totodată, o legătură mai puternică cu comunitățile în care se va desfășura analiza.

Metodele de cercetare aplicate vor include: 1/ studiu teoretic și documentare; 2/ consultarea arhivelor, specialiștilor, istoricilor și arhitecților pentru analiza istoriei locuințelor colective socialiste
Tea in the Neighbourhood (Ceai în Cartier/ Ce ai în Cartier?) was to use an interdisciplinary approach to start a different kind of architectural analysis, through discussions, surveys, interviews, a collective written and drawn journal, which will begin to explore the overlapping layers of meaning in the architecture of the socialist type- apartment building, which we began to study using the intersections of comic strips and architecture.

\section{Materials and Methods}

Type-apartment building blocks' Diaries project can serve as a social hub and informal learning space between all parties involved and negotiates hierarchies, opens dialogues, underlining the fact that architecture is a process, when it is designed, as well as when it is used. This program will work as a testing ground for new learning methods, rethinking the documentation and research experiences and esteeming common knowledge of the everyday life, alongside the residents of the space.

The project as a central programmatic entity brings together people from different backgrounds and allows less formalized exchanges of knowledge and most of the stages of the project will be done in collaboration with the dwellers. This approach increases the awareness and visibility of this research and learning platform, while creating a stronger connection with the communities in which the analysis will take place.

The research methods applied will include: 1/ theoretical study and documentation; 2/ consulting archives, specialists, historians and architects for the analysis of the history of socialist type-apartment- 
tipizate; 3/ ateliere de desen și machetare alături de locuitori; 4/ o serie de evenimente (expoziții, discuții, întâlniri) pentru a încuraja interacțiunea între toate părțile implicate în proiect; 5/ ateliere de co-design alături de studenți arhitecți și locuitori; 6/ interviuri; 7/ jurnal scris și desenat. building blocks; 3/ drawing \& modelling workshops with the dwellers; 4 / a series of events (exhibitions, discussions, gatherings) to encourage all the parties involved to connect; 5/ co-designing workshops with architectural and design students and dwellers; 6/ interviews; 7/ drawn and written journal.

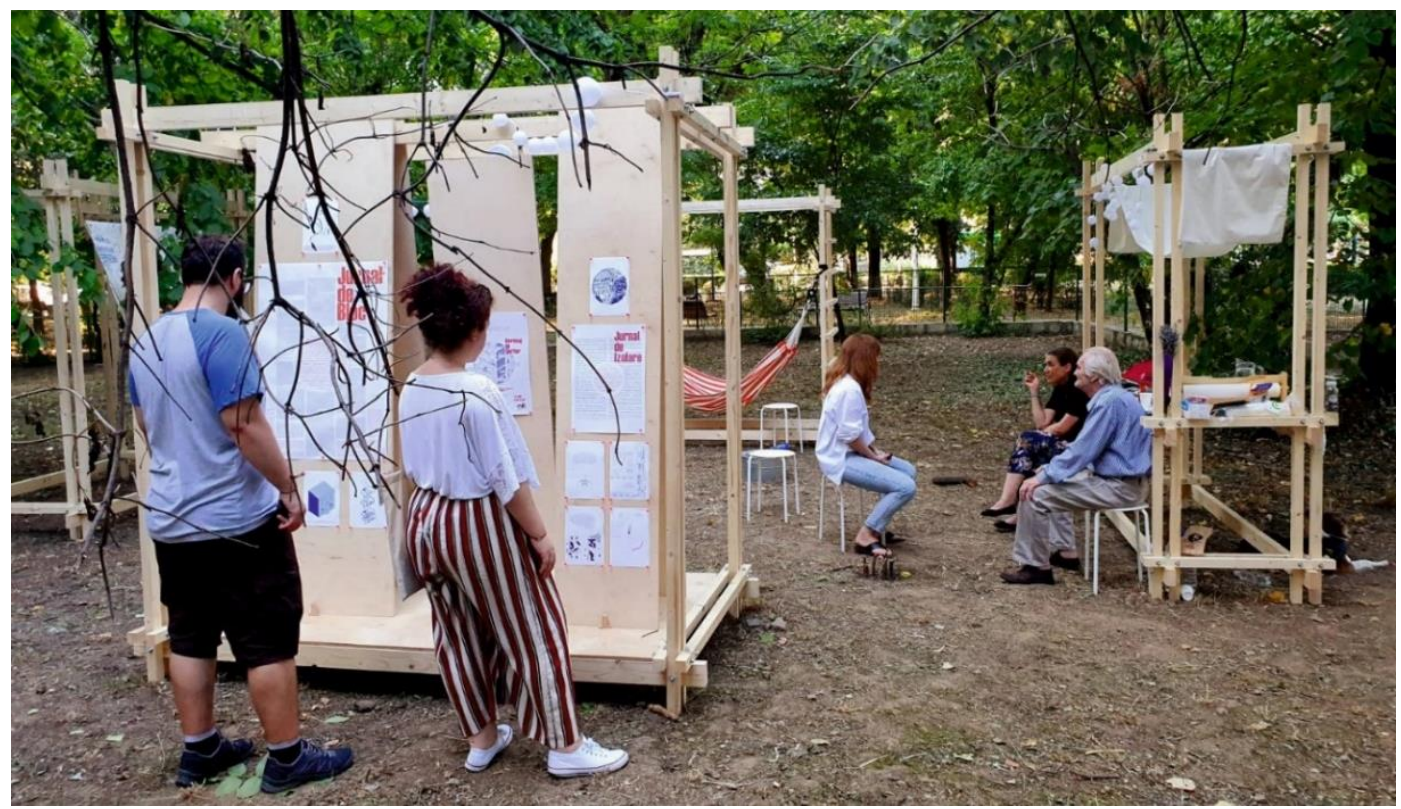

Fig. 3. Vernisaj de Cartier. Imagine de Andrei Dumitrașcu/ Neighbourhood's Opening. Image by Andrei Dumitrașcu.

Acest articol va prezenta rezultatele celor două prime evenimente hibride, Vernisaj de Cartier și Ceai în Cartier/ Ce ai în Cartier?, care au adunat, în cele 3 zile dedicate fiecărui eveniment, expoziții, discuții, întâlniri și realizarea unui jurnal colectiv scris și desenat.
In this article we will present the results of the first two hybrid events, Neighbourhood's Opening (Vernisaj de Cartier) and Tea in the Neighbourhood (Ceai în Cartier/ Ce ai în Cartier?), which gathered, in the 3 days dedicated to each event, exhibitions, discussions, meetings and the creation of a written and drawn collective diary. 


\section{Pregătirea evenimentelor}

Experiența acumulată în crearea și conducerea un număr considerabil de experimente și ateliere de cercetare a spațiul construit, alături de copii, studenți sau adulți, atât în România, cât și în alte țări precum Slovenia, Belgia, Namibia sau Brazilia, a jucat un rol important în felul în care am organizat etapele proiectului, am interacționat cu participanții și am îndeplinit sarcinile propuse. Atelierul Arhitecți pitici (2011), din București, SuperSimetria (2012), în Nordul Namibiei, Citirea spațiului arhitectural: Căminele Tei, ale Universității de Arhitectură și Urbanism"Ion Mincu" (2014), Super Erou în Politehnică (2015), Benzi desenate despre arhitectura Favelei Rocinha (2019), din Rio De Janiero, Brazilia sunt doar câteva din atelierele la care am lucrat, în timp ce mi-am dezvoltat cercetarea despre intersecțiile dintre banda desenată și arhitectură.

Folosind avantajele mediului grafic hibrid și flexibil al benzilor desenate, care combină, în alcătuirea lor, elementul narativ, spațiul și mișcarea (Ahrens 2010), alături de un alt coleg arhitect, Andrei Dumitrașcu, am decis să ilustrăm analiza straturilor suprapuse de interpretări, modificări și adaptări aduse spațiului comunității conturate în locuințele colective de 10 etaje, construite în anul 1968, pe strada Câmpia Libertății, din București, în care locuim de aproximativ 5 ani. Ne-am asumat rolul de detectiv al spațiului arhitectural, ca o consecință a găsirii unor scrisori vechi, în fața intrării în bloc, descoperind prin ele, Bucurestiul anilor 1960. Totodată am decis să adăugăm analizei noastre, un alt strat de analiză personală a perioadei copilăriei mele, petrecute întrun apartament identic, dintr-un oraș mic din sud-

\section{The preparatory work done}

The experience already accumulated creating and conducting a considerable number of experiments and workshops researching the built space, both with children, students and grown individuals, in Romania, as well as in other countries as Slovenia, Belgium, Namibia or Brazil, played a decisive role in the manner in which I organized the stages of the project, I interacted with the participants and fulfilled all the proposed tasks. The Little Architect workshop (2011), in Bucharest, SuperSimetry (2012), in North Namibia, Reading the architectural space: Tei Dorms, University of Architecture and Urban Planning "Ion Mincu" (2014), Bucharest, Super Hero in the Polytechnic University (2015), Architectural Comics in The Rocinha Favela (2019), Rio De Janiero, Brazil are just a few of the workshops I worked on, while I developed my research about the intersections between architecture and comic strips.

Using the advantages of the flexible hybrid graphic medium of comic strips, which combines, in their structure, the narrative element, space and movement (Ahrens, 2010), another fellow architect, Andrei Dumitrașcu and I, decided to illustrate the analysis of the juxtaposed layers of interpretation, modifications and adaptations made to the space of the community of the 10 floors apartment building, built in 1968, on Câmpia Libertății street, in Bucharest, in which have been living for approximate 5 years. We assumed the role of the detective of the architectural space, as a consequence of the finding of old letters, in front of the entrance of our building block, discovering through them, the Bucharest of the 1960s. At the same time, we decided to add to our analysis, 
estul României. Întreaga experiență a fost detaliată în articolele Building's diaries și My building block. A sequential architectural story iar ilustrațile care au acompaniat textul au fost expuse la International Comics Festival, "Salon Stripa" SKC Belgrad, Serbia, în anul 2018 și în anul 2019. În timpul experienței recente a perioadei de autoizolare, am continuat să explorăm, în detaliu, prin intermediul unui jurnal desenat, arhiva stratificată închisă în locuitorii clădirii, dar și în spațiile care le găzduiesc amintirile.

Așa cum am menționat mai sus, am început investigarea comunității formate în clădirea de locuințe colective socialiste tipizate în care locuim, ca o consecință a găsirii unui set de scrisori vechi de 49 de ani, care urmăresc o emoționantă poveste de dragoste, a doi colegi de muncă, precum și evoluția bolii a fragilei protagoniste, Katerina. Procesul de a pune cap la cap toate biletele, felicitările și scrisorile găsite aruncate în zăpadă, în timpul reabilitării termice a blocului în care locuim, tristețea dulce a tumultoasei povești de dragoste și etapele de evoluție ale bolii complicate a Katerinei, explicate partenerului ei, m-au bântuit o perioadă lungă de timp. În timp ce am încercat să găsim proprietarul de drept care rătăcise scrisorile, cel mai probabil din unul dintre balcoanele eliberate de către muncitorii zeloși, am devenit detectivi ai spațiului locuit și am documentat întreaga experiență printr-o serie de texte și ilustrații, adunând în ele orice detaliu relevant pentru analiza noastră. Am alăturat experiența mea acumulată cercetând numeroasele beneficii ale intersecțiilor dintre banda desenată și arhitectură, cu cea de arhitect, dar și de utilizator de another layer of personal analysis, of my childhood period, spent in an identical apartment, in a small town in the South- East of Romania. The entire experience was detailed in the articles Building's diaries and My building block. A sequential architectural story and the illustrations which accompanied the text were exhibited at the International Comics Festival,"Salon Stripa" SKC Belgrade, Serbia, 2018 and 2019. During the recent challenging experience of the self-isolation period, we continued to explore, in detail, throughout a drawn journal, the layered archive enclosed in the inhabitants of our building and in the spaces that host their memories.

As mentioned above, we began the current investigation of the community formed in the socialist building block in which we currently live in, as a consequence of finding a set of 49 years old letters, which follow the emotional love story, between two work colleagues, as well as the illness' evolution of Katerina, the fragile protagonist. The process of putting together the notes, the postcards and letters, thrown in the snow, during the thermic rehabilitation of the building block, the sweet sadness of the tumultuous love story and the stages of evolution of Katerina's complicated disease, narrated to her love interest, haunted me for a long time. While trying to find the owner of the letters, who somehow misplaced them, most likely from one of the balconies vacated by zealous workers, we became detectives of the space we inhabited and documented the entire experience, through a series texts and illustrations, gathering every relevant detail for our analysis. I combined my experience as a researcher, exploring the numerous benefits of the intersections between architecture and comic strips, architect as well as long-time personal user of the 
cursă lungă al spațiului locuințelor colective socialiste, pentru a pune bazele acestui proiect multidisciplinar (Dumitrașcu 2019).

Atât arhitecții cât și artiștii și-au manifestat interesul atunci când s-a adus în discuție analiza straturilor de semnificații dar și a problemelor care apar în cazul locuirii la bloc și au încercat să aducă diverse contribuții arhitecturale, prin care să optimizeze calitatea vieții în comunitățile formate în aceste spații. Un astfel de exemplu îl reprezintă proiectul Magic Blocks, desfășurat între anii 2009 și 2010, care include o etapă de cercetare, studiu de caz, mici intervenții urbane, conferințe și expoziții internaționale, o publicație și un documentar. Ideea principală a proiectului subliniază că procesul de reabilitare a locuințelor colective socialiste, care erau, în acel moment, în mare parte degradate și prezentau numeroase probleme economice și sociale, nu ar trebui să se concentreze doar pe reparațiile tehnice, dar ar trebui să propună și o regenerare urbană complexă, care să se concentreze atât pe aspectele spațiale cât și pe cele sociale. în 2010, proiectul s-a concentrat pe activarea spațiilor din spatele bulevardelor socialiste, din zona centrală (Magic Blocks. Behind the concrete curtain) iar studiul de caz ales a fost realizat pe Calea Moșilor. Echipa proiectului și-a propus să analizeze spații de dimensiuni reduse, neocupate și, aparent, fără proprietar, unde au și propus o serie de intervenții spațiale, alături de locuitorii din zonă (Ghenciulescu, Goagea, Vökler, 2009).

O altă intervenție care își propune să relateze poveștile locuitorilor locuințelor socialiste, precum și problemele, dar și oportunitățile care apar în aceste spații, este instalația Golden flat a artistului socialist type-apartment building, to put the bases of this multidisciplinary project (Dumitrașcu, 2019).

Both architects and artists expressed interest when discussing the analysis of layers of significance, but also the problems that arise in the case of living in a building block and tried to make various architectural contributions to optimize the quality of life in communities formed in these spaces. Such an example is the project Magic Blocks, conducted between 2009 and 2010, which included a research stage, case studies, small urban interventions, conferences and international exhibitions, a book and a documentary. The main idea of the project underlines that the rehabilitation of the socialist building blocks, which were at that point, in a large percentage, degraded and presented economic and social issues, should not focus only on the technical repairs, but should be a complex urban regeneration, which would also focus on spatial and social aspects. In 2010, the project focused on the activation of the spaces behind the socialist boulevards, in the central area (Magic Blocks. Behind the concrete curtain) and the chosen case study was Moșilor Avenue. The project's team aimed to take into discussion small, unoccupied and unclaimed spaces where a variety of interventions have been organized, alongside the inhabitants of the area (Ghenciulescu, Goagea, Vökler, 2009).

Another intervention, that aims to tell stories about the inhabitants of socialist housing, as well as the problems, but also the opportunities that appear in these spaces, is the Golden flat installation, by the 
Alexandru Potecă. Pentru o perioadă de doi ani, artistul a colecționat, depozitat și catalogat peste 300 de obiecte din perioada comunistă, culese de pe străzile din București, pe care, mai târziu, le-a transformat, îmbrăcându-le în foiță de aur și acoperindu-le cu vopsea aurie. Spunând despre el că se consideră mai degrabă un atent colecționar de povești decât un colecționar de obiecte, Potecă a recreat, cu o mare atenție pentru detalii, spații de locuit uitate, din perioada comunistă din România (Ciocan, Hendrikse, Rus Bojan, Teeuwise, 2015).

\section{Vernisaj de Cartier}

Acest exercițiu de documentare reprezintă o primă etapă a proiectului de trei ani, Jurnalele Blocurilor, care își propune să contureze o platformă ce încurajează dezvoltarea de metode alternative de investigare, analizare și proiectare a arhitecturii. Întregul proiect are ca scop reevaluarea relației ierarhice dintre arhitect și utilizatorul spațiului proiectat, conectând, în același timp, actori civici, profesioniști, arhitecți, studenți arhitecți și locuitori ai locuințelor colective socialiste, într-un proces etapizat, pentru a se facilita un schimb de informații.

Vernisaj de Cartier și-a propus să provoace noi legături între membrii comunității formate în ansamblul de locuințe colective din strada Câmpia Libertății, prima comunitate dintre cele trei propuse către analiză, pe perioada desfășurării proiectului, să încurajeze viitoare demersuri similare și să deschidă drumul către alte explorări experimentale. De asemenea, nu am putut să nu observăm că, în timpul stării de urgență, care s-a desfășurat în primăvara acestui an, spațiile din jurul blocului în care locuim, au devenit intens folosite de locuitorii din cartier. artist Alexandru Potecă. For a period of two years, the artist collected, stored and catalogued more than 300 objects from the communist period, from the streets of Bucharest, which he later transformed, using gold leafs and gold paint. Considering himself more of a careful collector of stories rather than a collector of objects, Potecă recreated, with great care for details, lost living spaces of the communist Romanian era (Ciocan, Hendrikse, Rus Bojan, Teeuwise, 2015).

\section{Neighbourhood's Opening}

This documentation exercise is the first phase of a three year Type-apartment building blocks' Diaries project, which aims to outline a platform that encourages the development of alternative methods of investigation, analysis and designing architecture. The entire project aims to re-evaluate the hierarchical relationship, between the architect and the user of the designed space, connecting, at the same time, civic actors, professionals, architects, architectural students and inhabitants of socialist collective housing, in a staged process, to facilitate an exchange of information.

Neighbourhood's Opening set out to provoke new connections between the members of the community formed in the type-apartment building block, from Câmpia Libertății street, the first community of the three proposed for analysis, during the project, to encourage future similar projects, but also to pave the way for a diverse range of experimental explorations. Also, we could not help to observe that during this spring, troughout the state of emergency, the spaces around our building block were intensively populated by the 
Prezența zilnică a acestora, în spații comune, a încetat odată ce restricțiile s-au relaxat. Locuitorii din comunitatea în care locuiesc s-au reîntors la obiceiul lor de a parcurge drumul, în linie dreaptă, de la mașina personală la ușa apartamentului, fără a mai zăbovi în spațiile comune. Ce s-ar întâmpla dacă am folosi, în mod corect și permanent, toate opțiunile oferite de spațiile adiționale locuințelor colective, în care trăim?

Deschiderea acestui dialog, printr-un atelier hibrid de discuții, explorări grafice, expoziție colectivă, dar și relaxare la umbra teilor, ar putea fi primul pas către conturarea unei arhive în care putem colecționa suma de evenimente trăite de indivizi diferiți, care locuiesc în același spațiu, într-una dintre cele mai dificile perioade din ultimii ani. Astfel, am decis să aducem experiența de a vizita o galerie de artă în comunitate, mai exact în fața blocului și să prezentăm locuitorilor experiența noastră acumulată în urma analizării clădirii în care locuim, totodată încurajându-i să își spună povestea lor, trăită în același spațiu.

\section{Rezultatele evenimentului Vernisaj de Cartier}

Evenimentul, care s-a întins pe durata a trei zile, Vernisaj de Cartier, a fost unul dintre proiectele selectate pentru a face parte din demersul propus de către organizatorii Street Delivery 2020, de a încuraja arhitecții și artiștii să lanseze propuneri de a trata spațiile nefolosite din preajma locuinței lor, pe perioada de urgență, pentru a crea un festival modular, întins în tot orașul. Am ales să prezentăm, în cadrul acestui eveniment, rezultatele cercetării noastre asupra spațiului blocului în care locuim, sub inhabitants. The dwellers' presence, in the shared spaces, ceased once the restrictions were relaxed. The inhabitants of the community in which I live in, returned to the habit of going straight from their car to their apartment, without stopping in the common areas. What would happen if we used, correctly and permanently, all the options offered by the additional spaces around our building block?

The opening of this dialogue, through a hybrid workshop of discussions, graphic exploration, collective exhibition, but also relaxation, at the shade of lime trees, could be the first step in building an archive of different experiences of a group of individuals using the same space, in one of the tensest periods of recent years. So, we decided to bring the art gallery experience in the community, precisely in the front of our building block and to present its residents with our experience gained after analysing the building in which we live, while giving them courage to tell their story, as well.

\section{Results of the Neighbourhood's Opening event}

The three days event, Neighbourhood's Opening, was one of the projects selected to be part of the proposed approach by the organizers part organizers of Street Delivery 2020 festival to encourage architects and artists to launch proposals in order to treat unused spaces around their home, during the emergency period, to create a modular festival, spread throughout the city. We chose to present, during this event, the results of our research, exploring the space of building block in 
forma unui jurnal scris și desenat, ca un punct de plecare pentru deschiderea dialogului cu locatarii cartierului nostru și să creăm noi conexiuni cu oameni care s-au arătat interesați să își doneze timpul și cunoștințele pentru viitoarele etape ale proiectului.

Vizitatorii evenimentului, încurajați de prezența noastră constantă, pe parcursul celor trei zile, în Iulie, în grădina din curtea blocului, s-au oferit să contribuie proiectului încă din momentul asamblării modulelor expoziționale de lemn. Ceea ce credeam că va necesita o intensă încurajare și mediere din partea noastră, s-a întâmplat într-un mod natural. Odată lămuriți în legătură cu privire la scopul și durata intervenției noastre, locuitorii din zonă au început să își manifeste dorința de a contribui instalației noastre. Fie că a fost vorba de o farfurie de mâncare donată, miere pentru limonada pe care urma să o pregătim, oferte de spray contra țânțarilor, sau cărți de poezie și proză donate de către 2 poeți și un prozator, care au și ales să improvizeze un cenaclu, citind fragmente din lucrările lor, sau încântarea cu care atât copiii cât și adulții au contribuit jurnalului scris și desenat, consecința directă a fost că oamenii au început să creeze noi legături, să își pună întrebări legate de spațiul pe care îl locuiesc, să se simtă încurajați de prezența unor profesioniști care doresc să le asculte opinia, dar și de posibilitatea de a contribui unui proiect realizat în cartierul lor.

Una dintre cele mai importante observații este aceea că toți vizitatorii Vernisajului de Cartier, pe lângă faptul că doreau să contribuie, să interacționeze, doreau să fie auziți. Au nevoie de un cadru, de un program, de intervenții fizice, de specialiști care să-i ghideze, să-i asculte și să which we live, in the form of a written and drawn diary, as a starting point for opening a dialogue with the residents of our neighbourhood and create new connections with people who have shown interest in donating their time and knowledge for the future stages of our project.

The visitors, encouraged by our constant presence in those three days, in July, in the building's garden, offered to contribute to our experiment, from the moment of assembling the wooden exhibition modules. What we thought it would take a long time to convince and encourage them to do, happened very natural. Once clarified about the purpose and duration of our intervention, the inhabitants from the area began to express their desire to contribute to our installation. Whether it was a plate of donated food, honey for the lemonade we were going to prepare, mosquito spray offers, or books of poetry and prose donated by 2 poets and a prose writer, who also chose to improvise a cenacle, reading excerpts from their work, or the delight with which both children and adults contributed to the written and drawn diary, the direct consequence was that people started to make new connections, to ask questions about the space they live in, to feel encouraged by the presence of professionals who want to listen to their opinion, but also to have the possibility to contribute to a project carried out in their neighbourhood.

One of the most important observations was that all of our visitors of the Neighbourhood's Opening, beside the fact that they wanted to contribute, to interact, they wanted to be heard. They need a framework, a program, physical interventions, specialists to guide them, listen to them and analyse, 
analizeze, alături de ei, informația. Același lucru era valabil fie că discutam de băiatul de 3 ani, care vorbea într-un dialect cunoscut doar de părinții lui, de vecinul nostru de 9 ani, foarte încântat să contribuie instalației noastre cu hamacul său, de adolescentul inteligent și timid care îngrijea pisici, câini sau păsări rănite și abandonate, de inginerul pensionar, pasionat de Einstein, de sculptorul amator, absolvent al Facultății de Studii Economice, de profesoara de matematică pensionară care ne-a povestit, cu multă savoare și autoironie despre experiența ei de a fi soacră, sau de studenta la Asistență Socială care era nerăbdătoare să se întoarcă în centrele în care desfășura activitatea de voluntariat. with them, the information. It was the same for the 3 year boy who spoke in a dialect only known by him and his parents, for the 9 year-old neighbour who was happy to complete our composition with his own hammock, for the shy and intelligent teenager who takes care of abandoned kittens, dogs and wounded birds, for the retired engineer who was fascinated by Einstein, for the amateur sculptor, who went to the Faculty of Economic Studies, for the retired math teacher who told us, with a lot of flavour and self-irony about her experience of being a mother-in-law, for the Social Welfare student, who was looking forward to returning to the centres where she volunteered.

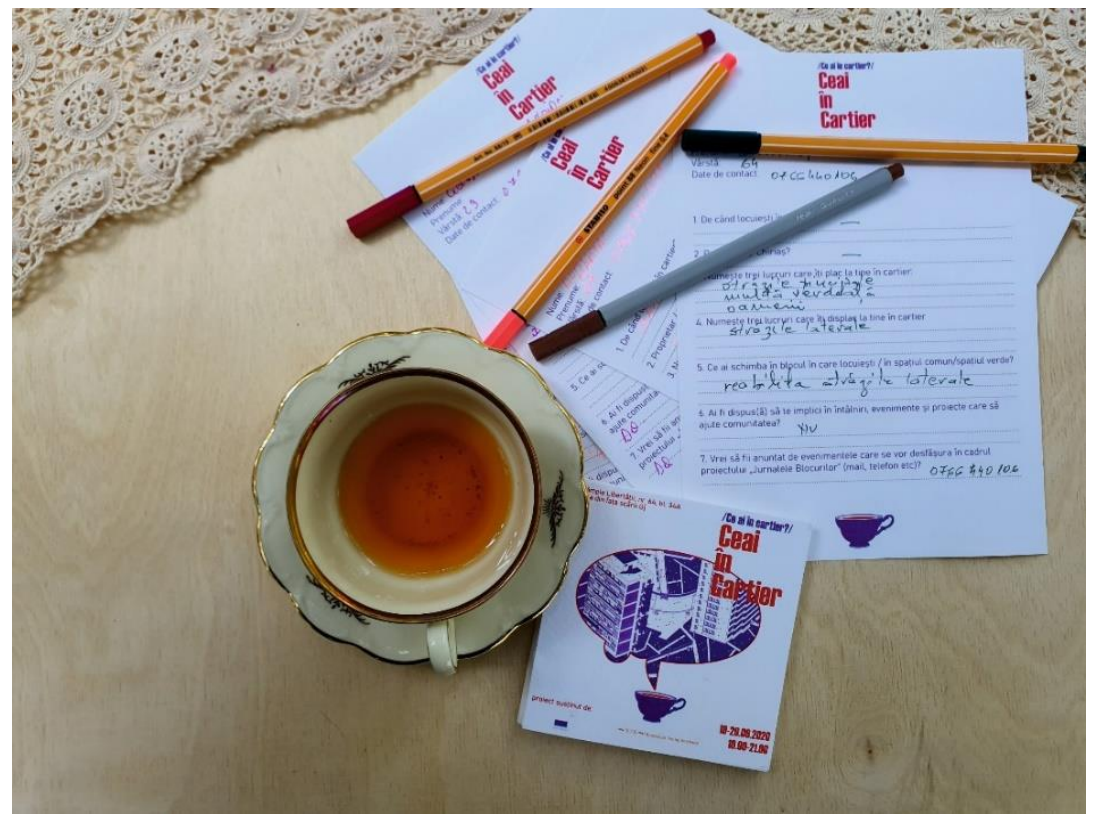

Fig. 4. Evenimentul Ceai în Cartier/ Ce ai în Cartier? Imagine de Gențiana Dumitrașcu./ Tea in the Neighbourhood event. Image by Gențiana Dumitrașcu. 
Rezultatele încurajatoare ale acestei prime inițiative ne-au oferit motivația necesară de a dezvolta instalația într-o intervenție permanentă și de a continua să documentăm, cu grijă, fiecare pas al proiectului.

\section{Evenimentul Ceai în Cartier/ Ce ai în Cartier?}

Deoarece proiectul Jurnalele Blocurilor a avut ocazia de a primi o finanțare, întinsă pe o perioadă de trei ani, din partea Romanian Young Academy, care este finanțată de Stiftung Mercator și Fundația Alexander von Humbolt, am putut să începem a doua etapă de documentare, în cartier, a cercetării noastre interdisciplinare. Scopul principal al primului eveniment a fost ca echipa noastră să se prezinte comunității, să facem cunoscută acesteia cercetarea și intențiile noastre. Ne-am bucurat că în timpul primului eveniment am avut ocazia să stabilim legături cu vizitatorii instalației noastre, dar și cu locatarii, iar, în evenimentul din luna Septembrie, ne-am propus să întărim aceste relații și să începem o bază de date (cu nume, prenume, număr de telefon, profesie) cu cei care și-au manifestat disponibilitatea de a contribui, donând timpul și cunoștințele lor, pentru a putea construi, alături de noi, mici intervenții arhitecturale. Ne-am propus să alcătuim și un scurt chestionar calitativ și o serie de interviuri înregistrate, prin care să înțelegem, în detaliu, experiența locuirii la bloc, a vizitatorilor intervenției noastre.

Am decis să folosim un joc de cuvinte pentru tema evenimentului (Ceai în Cartier/ Ce ai în Cartier?) dar
The encouraging results of this first initiative gave us the necessary motivation to develop the installation in a permanent intervention and to continue to document, carefully, every step of the project.

\section{Tea in the Neighbourhood}

Because we had the chance for Type-apartment building blocks' Diaries to receive a grant, for a three year period, from Romanian Young Academy, which is funded by Stiftung Mercator and Alexander von Humbolt Foundation, we were able to begin the second stage of documenting, of our interdisciplinary research, in the neighbourhood. The main focus of our first event was for our team to introduce themselves to the community, to make our research and intentions known. We were glad that during the first event we had the opportunity to establish connections with the visitors of our installation, but also with the tenants, and, in the September event, we set out to strengthen these relationships and start a database (with name, surname, telephone number, profession) with those who expressed their willingness to contribute, donating their time and knowledge, in order to be able to build, with us, small architectural interventions. We set out to compile a short qualitative questionnaire and a series of recorded interviews, through which we could understand, in detail, the experience of living in a building block, of the visitors of our intervention.

We decided to use a play of words for the theme of the event and (Tea in the Neighbourhood/ What do 
și pentru activitatea principală desfășurată. Astfel, am cules 21 de interviuri, cât timp am băut ceai cald, proaspăt preparat în modulele noastre, am mâncat fursecuri cu inserții florale, pregătite de Alexandra Andronic, iar seara am vizionat, un film francez, cât timp am mâncat popcorn, în curtea blocului nostru.

Prin chestionarul compus din șapte întrebări am rugat participanții la atelier să spună de când locuiesc în cartier, dacă sunt proprietari sau închiriază spațiul în care locuiesc, să enumere trei caracteristici ale comunității din care fac parte pe care le apreciază și alte trei de care nu sunt mulțumiți, iar dacă erau de acord să participe în etapele următoare la proiectul nostru, erau încurajați să își lase datele de contact.

\section{Rezultatele evenimentului Ceai în Cartier/ Ce ai în Cartier?}

Pe parcursul celor trei zile, în care am servit ceaiul în cartier, ne-am reîntâlnit cu o parte din participanții evenimentului Vernisaj de Cartier, dar am și avut ocazia să facem cunoștință cu un număr mai mare de locuitori din zonă. Dintre toți participanții la eveniment ne-am bucurat să observăm că un număr mare dintre ei au dorit să răspundă întrebărilor interviului propus de noi și că au fost de acord să contribuie, pe viitor, proiectului. Dintre cei care s-au oprit să dialogheze cu noi despre cartier, putem menționa inginerul, mândrul proprietar al unui exemplar superb Akita, hotărât să ne ofere consultanță în viitoarele intervenții arhitecturale, instalatorul pasionat de arhitectura românească tradițională, tehnicianul descendent al familiei Brâncuși, avocatul dispus să ne ofere consultanță you have in the Neighbourhood?) but also for the main activity carried out. Thus, we collected 21 interviews, while we drank hot tea, freshly prepared in our modules, we ate cookies with floral inserts, prepared by Alexandra Andronic and in the evening we watched a French movie, while we ate popcorn in our building block's garden.

Through the seven-question questionnaire, we asked the workshop's participants to document how long they have lived in the neighbourhood, if they own their home or not, while listing three characteristics of the community which they enjoy and other three they are not so happy with and if they agreed to contribute in the next stages of our project, they were encouraged to leave their contact details.

\section{Results of the Tea in the Neighbourhood event}

During the three days we served tea in the neighbourhood, we met with some of the participants of the Neighbourhood's Opening event, but we also had the opportunity to meet a larger number of residents from our community. Of all the participants in the event, we were glad to observe that a large number of the wanted to answer the questions of the interview and that they agreed to contribute, in the future, to the project. Of those who stopped to talk to us about the neighbourhood, we can mention the engineer, who was the proud owner of a superb Akita dog, determined to provide us with advice for future architectural interventions, the plumber passionate about traditional Romanian architecture, a technician who was a proud descendent of the Brâncuși family, the lawyer willing 
legală dacă vom întâmpina probleme în viitoarele evenimente desfășurate, profesoara care tocmai în acea zi sărbătorea 39 ani de căsătorie, băiatul de 9 ani, cu mâna în ghips, dar care avea mai multă energie decât întreaga noastră echipă, sau cele două studente la Litere, care, în timpul interviului, ne-au aflat viețile trecute, în cărțile de Tarot.

Atât baza de date cu informațiile locuitorilor din cartier care doresc să fie implicați și în următoarele evenimente ale proiectului, este în continuă creștere, cât și legăturile cu profesioniști din domenii conexe, cu care vom colabora pentru a descoperi mai multe informații despre istoria zonei studiate, dar și pentru a alcătui o serie de chestionare cantitative despre populația din comunitatea creată în Câmpia Libertății.

Din datele adunate în cadrul chestionarului scris și din interviuri, am concluzionat că majoritatea locuitorilor din zona studiată sunt încântați de vecinătatea parcului I.O.R., considerându-I centrul de interes al cartierului. Au menționat, de asemenea, că sunt mulțumiți, cu foarte mici excepții, de calitatea oamenilor care îi înconjoară, de faptul că este, în mare parte, un cartier liniștit, cu un număr redus de infracțiuni. Situațiile problematice apar atunci când se aduc în discuție: proasta întreținere a unor artere secundare, gălăgia provocată în locurile de joacă destinate câinilor, care se află prea aproape de clădiri, oamenii fără adăpost, care, deși erau considerați inofensivi, erau văzuți ca pe un inconvenient, reprezentanții politici ai sectorului pe care locuitorii nu îi investesc cu prea multă încredere, acuzându-i că nu ar avea o strategie consecventă. O mare parte din locuitorii vârstnici au declarat că se simt invizibili și izolați, găsind o sursă de confort doar în micile discuții tensionate, purtate to provide us with legal advice if we encounter problems in future events, the teacher who just that day was celebrating her $39^{\text {th }}$ marriage anniversary, the 9 year-old boy, with his hand in plaster, but who had more energy than our entire team, or the two young girls studying literature who during the interview, found out our past lives, in Tarot cards.

Both the database with information about the residents from the neighbourhood who wanted to be involved in the next events of the project, is constantly growing, as well as the connections with professionals in related fields, with which we will collaborate to discover more data about the history of the studied area, but also to compile a series of quantitative questionnaires about the population of the community created in Câmpia Libertății Street.

From the data gathered through the written survey and interviews, we concluded that almost all the neighbours from the studied area are delighted with the proximity of I.O.R. park, considering it the centre of interest of the neighbourhood. They, also, mentioned that they are satisfied, with very few exceptions, with the quality of the people surrounding them, with the fact that it is mostly, a quiet neighbourhood, with a law crime rate. Problematic situations arise when are discussed: the poor condition of some of the side streets, the noise caused from the playgrounds for dogs, located too close to the building blocks, the homeless people, who although were considered harmless, were seen as an inconvenience, the political representatives of the district, whom the inhabitants do not invest with too much confidence, accusing them of not having a consistent strategy. A large part of the elderly residents felt invisible and isolated, finding comfort only in short tensioned discussions, between each 
între ei, pe băncile aflate în imediata vecinătate a blocurilor în care locuiesc.

Am observat existența unei lipse de comunicare atât între locuitorii din zonă, profesioniști, oamenii politici, reprezentanți ai sectorului, dar și între locatari, schimbul de idei și informații fiind defectuos. Toată lumea dorea să vorbească. Nimeni voia să asculte. Își doreau să contribuie, să lucreze împreună, dar se simțea lipsa unui mediator, a unei structuri, a unui set de linii directoare și a unor scopuri clare. other, sitting on the benches in the immediate vicinity of the building blocks in which they live in.

We observed a lack of communication both between the inhabitants of the area, professionals, politicians, representatives of the district, but also between the tenants, the exchange of ideas and information being defective. Everybody wanted to talk. Nobody wanted to listen. They wanted to contribute, to work together, but they were lacking a mediator, a structure, a set of guidelines and a set of clear targets.

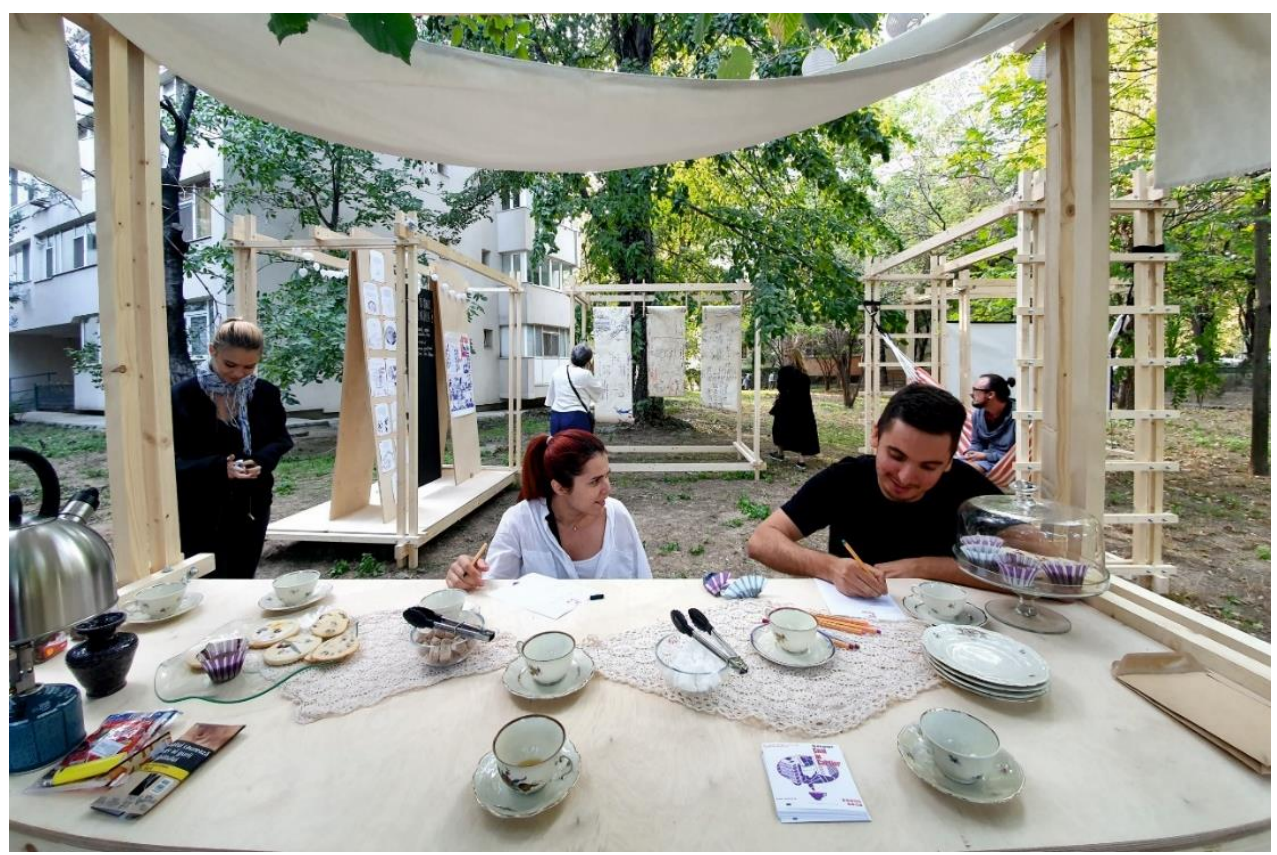

Fig. 5. Evenimentul Ceai în Cartier/ Ce ai în Cartier? Imagine de Gențiana Dumitrașcu/ Tea in the Neighbourhood event. Image by Gențiana Dumitrașcu. 


\section{Un fel de concluzie}

Expozițiile, atelierele de desen și machetare, precum și atelierele de co-design și intervențiile arhitecturale incluse în proiectul Jurnalele Blocurilor sunt evenimente participatorii, încurajând locatarii locuințelor colective socialiste tipizate să se implice și să participe, validându-le problemele, amintirile, direcțiile, respectându-le opiniile, oferindu-le totodată o platformă prin care să se poată face auziți, dar și să primească o consultare directă. Discuțiile și dialogurile care urmează să se desfășoare între locatari și profesioniști, actori civici, reprezentanți politici ai sectorului, au ca scop realizarea unui schimb informal de cunoștințe, pentru ca toate părțile implicate să poată să își construiască o imagine de ansamblu a problemelor pe care le întâmpină în domeniul lor. Proiectul, în forma sa finală, va consta într-o bază de date complexă, care o să includă 3 studii de caz, disponibilă atât profesioniștilor cât și nonspecialiștilor, dar, va fi și o puternică motivație pentru a reconsidera maniera în care autoritățile desfășoară reabilitarea locuințelor colective.

Deși cele două evenimente, Vernisaj de Cartier și Ceai în Cartier/ Ce ai în Cartier?, care fac parte din evenimentele desfășurate în primul dintre cele trei studii de caz, care aparțin proiectului Jurnalele Blocurilor, au fost doar primul pas în a-i cunoaște și în a lucra alături de locuitorii din zona studiată, pe care am analizat-o anterior, în benzile desenate arhitecturale create în ultimii doi ani, am fost încurajați de rezultatele promițătoare și de apetitul pentru colaborare al participantilor. Vom continua să implicăm locatarii în toate etapele viitoare ale proiectului, negociind cu ei, incluzându-i în dezbateri

\section{Some kind of conclusion}

The exhibitions, drawing and modelling workshops, as well as the co-design and building workshops, included in Type-apartment building blocks' Diaries project, are all participatory events, encouraging the residents of the socialist type-apartment building blocks to engage and participate, validating their problems, their memories, their directions, respecting their opinions, giving them a platform, to be heard and seriously consulted. The discussions and dialogues to be held between tenants and professionals, civic actors, political representatives of the district, aim to achieve an informal exchange of knowledge, so that all parties involved can build an overview of the problems they face in their field. The project, in its final form, will consist of a complex database, which will include 3 case studies, available to both professionals and non-specialists, but it will also be a strong motivation to reconsider the way in which authorities carry out the rehabilitation of the collective building blocks.

Although the two events, Neighbourhood's Opening and Tea in the Neighbourhood, belonging to the first year, of the three year Type-apartment building blocks' Diaries project, were just the first step in connecting and working alongside the residents of the community we have been studying, which we previous analysed, in the last two years, in the architectural comic strips, we were encouraged by the promising results and the appetite for collaboration of the participants. We will continue to involve the residents in the future stages of our project, negotiating with them, including them in 
cu arhitecți, antropologi, sociologi etc., încercând să răspundem nevoilor lor imediate, în timp ce vom încerca să ținem cont de sugestiile acordate pentru micile intervenții arhitecturale realizate în comunitatea în care trăiesc, astfel încurajându-le responsabilizarea față de spațiul pe care îl locuiesc și față de cel pe care îl traversează zi de zi.

Arhitectura adună laolaltă viețile oamenilor, iar atunci când arhitectul proiectează o casă, proiectează, în același timp, viața viitorilor săi utilizatori. Dar, în momentul în care locuitorul începe să folosească spațiul, modelează, la rândul său, arhitectura propusă de arhitect. Astfel, casa începe să se transforme alături de acesta, câștigând în mod constant un nou strat, o nouă semnificație. Există un mare potențial pentru a spune povești despre arhitectura construită, folosindu-ne de elementul narativ, astfel, având oportunitatea, ca specialiști, să analizăm fiecare strat al structurii locuite, a acestei arhive vii, aflată departe de momentul în care a fost dată în folosire. the debates with architects, anthropologists, sociologists etc., trying to respond to their immediate needs, while also taking into account the suggestions given for the small architectural interventions made in the community in which they live, thus encouraging them to take responsibility for the space they live in and for the one walk through every day.

The architecture of a building brings people's lives together and when an architect designs a house, he shapes, in the same time, the life of its future occupants. But, when the inhabitant starts to use the space, he, in turn, models the architecture proposed by the architect. Thus, the house begins to transform with it, constantly gaining a new layer, a new meaning. There is a great potential for telling stories about the built architecture, using the narrative element, thus, having the opportunity, as specialists, to analyse every layer of the inhabited structure, of this living archive, far from the moment when it came into use.

Acknowledgements: Finanțat de Romanian Young Academy, instituție sprijinită de Fundația Stiftung Mercator și Fundația Alexander von Humbolt/Financed through Romanian Young Academy, funded by Stiftung Mercator and Alexander von Humbolt Foundation

\section{Referinţe/ References}

Ahrens, J. and Meteling, A (2010). Comics and the City. Urban Space in Print, Picture and Sequence. New York: Continuum.

Biciușcă, F. (2005). Experimentul Cățelu. București: LiterNet. 
Ciocan I., Hendrikse C., Rus Bojan M., Teeuwise J. (2015). Transformation. Romanian Sculpture 25 Years after the Revolution. București: Vellant.

Dumitrașcu, G. (2019). My building block. A sequential architectural story. București: Arhitext.

Ghenciulescu Ș., Goagea C., Vökler K. (2009). Magic Blocks. București: Zeppelin.

Ioan, A. (1999). Khora. Teme și dificultăți ale relației dintre filosofie și arhitectură. București: Paideia.

Zahariade, A. (2011). Architecture in the communist project. Romania 1944- 1989 [Arhitectura în proiectul comunist. România 1944-1989]. București: Simetria. 